\title{
First record of the feather-legged fly Trichopoda pennipes (Fabricius, 178I) (Diptera Tachinidae) a parasitoid of the southern green stink bug Nezara viridula (Linnaeus, 1758) (Hemiptera Pentatomidae) in Algeria
}

\author{
Ahlem Meriem*, Lina Aitaider, Bahia Doumandji-Mitiche \& Abderrahmane Chebli \\ Lab. protection des végétaux en milieux agricoles et naturels contre les déprédateurs des cultures. Département de \\ Zoologie Agricole et Forestière. ENSA, El Harrach, ES1603, Algeria; e-mail: 1.aitaider@edu.ensa.dz, \\ b.doumandji@ensa.dz,a.chebli@edu.ensa.dz \\ *Corresponding author, e-mail: a.meriem@edu.ensa.dz; meriemahlem94@gmail.com
}

\begin{abstract}
Between 2018 and 2019 we conducted a comprehensive study on the southern green stink bug Nezara viridula (Linnaeus, 1758) (Hemiptera Pentatomidae) for the first time in Algeria. On August 2019 specimens of the feather-legged fly Trichopoda pennipes (Fabricius, 1781) (Diptera Tachinidae) were detected for the first time from reared parasitized adults of Nezara viridula (L.) (Hemiptera: Pentatomidae) which were sampled from tomato crop in an agricultural region called Ouled Hadedj in the eastern part of Mitidja in Algeria. Trichopoda pennipes is an endoparasitoid of the stink bug Nezara viridula. This study provides the first record of this Nearctic tachinid fly and its genus in Algeria which can also be a very useful addition for biodiversity and for the geographical distribution of this species. Morphological description of the detected parasitoid species and Colored photographs of the parasitoid and parasitized host are provided.
\end{abstract}

KEY WORDS Biological control, biodiversity, distribution, parasitism, tomato crop, Mitidja.

Received 25.02.2020; accepted 30.04.2021; published online 24.07.2021

\section{INTRODUCTION}

The parasitoid tachinid species Trichopoda pennipes (Fabricius, 1781) (Diptera Tachinidae) is native to the Nearctic region (Salerno et al., 2002). This species is an imaginal and infrequently a nymphal parasitoid of many different bugs (Harris \& Todd, 1981; Ruberson et al., 2010). In its natural geographic area, its host range includes several species of various Heteroptera families as Alydidae, Coreidae, Pentatomidae, and Pyrrhocoridae (Francati et al., 2019). Besides, the introduction of Nezara viridula (Linnaeus, 1758) (Hemiptera Pentatomidae) into the North of America in 1700 , make it as an additional host of T. pennipes (Jones, 1988). Trichopoda pennipes is commonly known as the feather-legged fly because of the feathers existing on the posterior legs (Worthley, 1924). This fly is an endoparasitoid of the southern green stink bug Nezara viridula adults and final instars (Todd, 1989). It was introduced from the USA into Australia to control bugs, especially Nezara viridula (Waterhouse, 1998). In Europe, this tachinid fly was accidentally introduced to Italy and it was detected for the first time in 1988 near Rome (Colazza et al., 1996). It was recorded in several other Mediterranean countries like southern France (Tschorsnig et al., 2000), Spain (Peris, 1998; 
Tschorsnig et al., 2000), Slovenia (De Groot et al., 2007), Netherlands (Zeegers, 2010), Albania (Tschorsnig et al., 2012), Hungary (Sándor, 2014) and Portugal (Pétremand et al., 2015). In 2006 exactly in Switzerland, T. pennipes was identified for the first time in Ticino (Obrecht, 2014; Pétremand et al., 2015). It was introduced and well established in Hawaii for the biological control of Nezara viridula (Davis, 1964; Michael, 1981). In Egypt, the species was detected for the first time from parasitized adults and nymphs of the southern green stink bug Nezara viridula (El-Hawagry et al., 2020). The fly has generally 2 to 3 generations per year. The female can lay one or more whitish plano-convex, non-incubated eggs upon the body of the adult and occasionally on final nymphal instar of the bug. The majority of eggs are placed on the sides of the thorax (Worthley, 1924; Salerno et al., 2002). After hatching, the larvae of Trichopoda pennipes bore the tegument of the host and enter inside and feed on its fluids for about 2 weeks. Then just one mature larva leaves the bug's body through its anal extremity and form puparia, subsequently the bug dies (Worthley, 1924). Pupation lasts between 2 to 4 weeks (Cargnus et al., 2011) then the emerged adults of $T$. pennipes feed on nectar (Worthley, 1924). In Algeria, Trichopoda pennipes and its host Nezara viridula have not been studied before. In this study we present the first record of the feather-legged fly $T$. pennipes. The study includes its morphology and biology.

\section{MATERIAL AND METHODS}

\section{Study area}

This study was carried out on 1 August 2019 in Ouled Hadedj in the eastern part of Mitidja in Algeria $\left(36^{\circ} 45^{\prime} 37,23^{\prime \prime} \mathrm{N}, 3^{\circ} 28^{\prime} 20,52^{\prime \prime} \mathrm{E}\right)$ (Fig. 1) as a part of a complete comprehensive survey of the pest Nezara viridula which was conducted between 2018 and 2019. The bugs were collected from tomato crop by hand sampling which was a very useful technique to facilitate and to make sure the recovery of the individuals alive. To study the behaviour of the bug, the individuals (adults and nymphs) were put for rearing in a plastic box $(30 \mathrm{~cm}, 20 \mathrm{~cm}, 12 \mathrm{~cm})$ in which we added Solanaceae plants as tomato and green pepper to ensure the life continuity of the bugs and they were transferred to an insectarium which is a room of constant temperature about $25^{\circ} \mathrm{C}$ in the

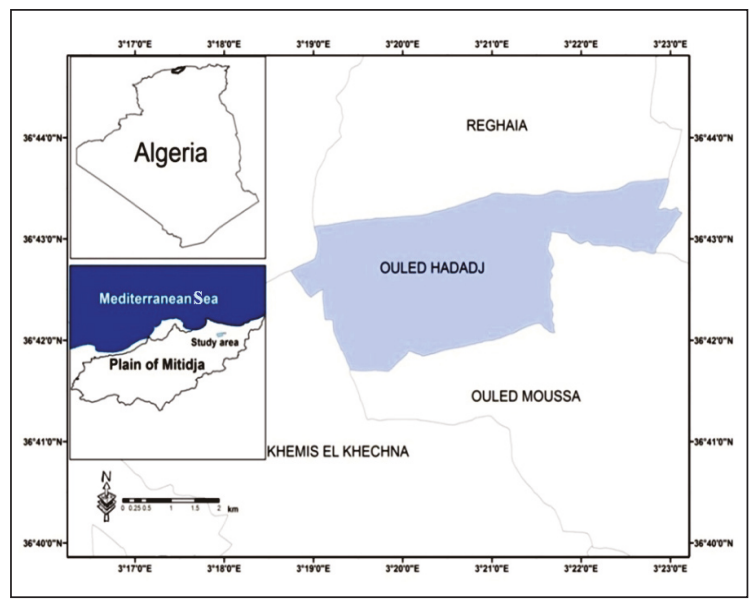

Figure 1. Location of the study region: Ouled Hadadj in the eastern part of Mitidja in Algeria.

Department of Zoology in the Superior National Agronomic School, Algeri.

There were 60 individuals of the southern green stink bug Nezara viridula, which were collected to be reared. The rearing of these bugs enabled us to observe that most of them were parasitized (about 40 parasitized individuals). They appeared carrying yellowish white tiny eggs on several parts of the body like head, thorax and scutelum from anterior and posterior sides (Fig. 2). The majority die before the emergence of the parasitoid, only 8 parasitized individuals remained, seven of them were adults and the eighth one was a final nymphal instar. We isolated each one of these 8 parasitized bugs separately in Petri dishes numbered from 1 to 8 , fed them with tiny slices of green pepper and tomato. Seven mature maggots of Trichopoda pennipes had emerged from the seven parasitized adults of Nezara viridula. The parasitized final nymphal instar died during the ecdysis. From the seven puparia formed there were just 4 adults of $T$. pennipes have been emerged. This study was based on 4 adult individuals ( 3 males and 1 female) of $T$. pennipes. The first of these individuals were a male found in 17 August 2019 in the Petri dish. Two another males were found in another two Petri dishes in 26 August 2019, after one day in 27 August 2019 a female of T. pennipes were found in another Petri dish. Both of the parasitoid and its host were identified and confirmed in the laboratory of zoology department in the Higher National Agronomic School (ENSA), Algiers. The identification was made by a specialist under a binocular magnifying glass using dry specimens and relying on searching 


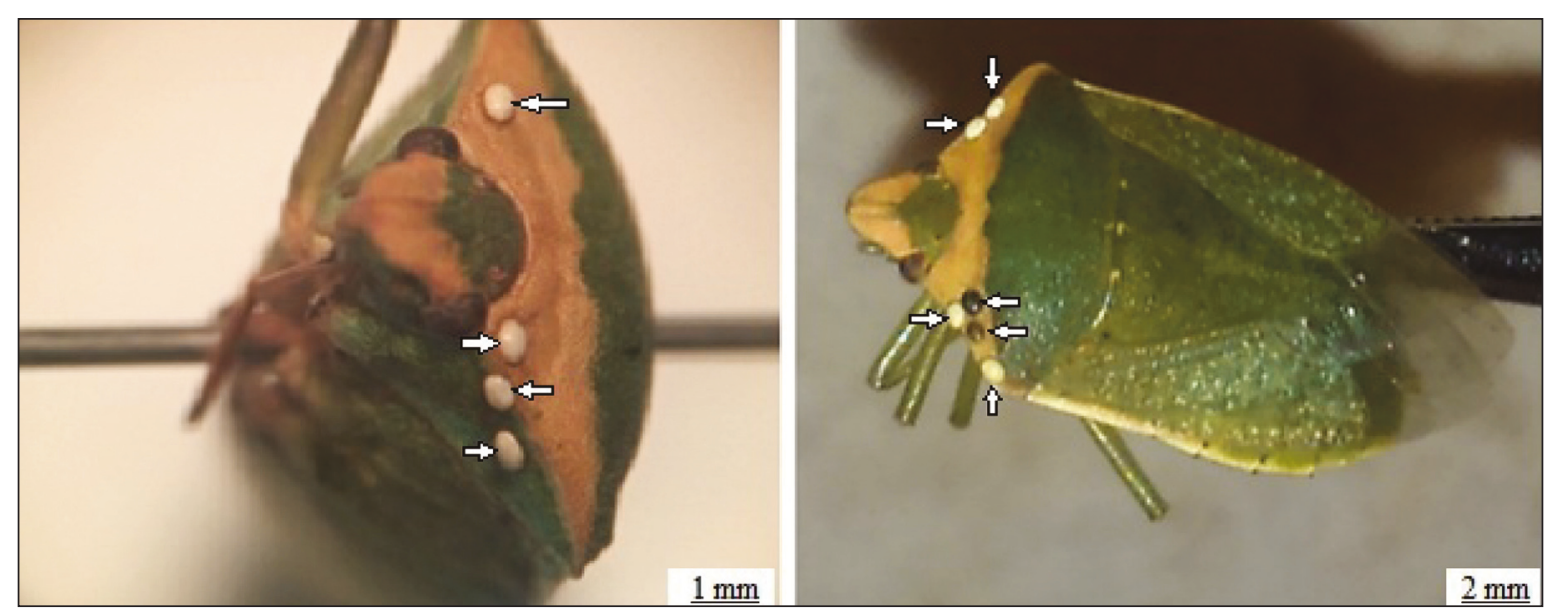

Figure 2. Specimens of Nezara viridula collected carrying yellowish white tiny eggs of Trichopoda pennipes on several parts of the body.

in several references and articles such as Worthley (1924), O’Hara (2013), Tschorsnig (2017). The typical host of the tachinid fly is the cosmopolitan pentatomid Nezara viridula which was confirmed relying on the insects' collection of the department's insectarium.

\section{RESULTS}

\section{Observation on Parasitoidsm}

We noticed that the parasitized bugs have a different behavior compared with the non-parasitized ones; the parasitized bugs were found very slow and stopped feeding on the green pepper and tomato slices. A parasitized adult of $N$. viridula in Petri dish number 1 was a female carrying four eggs, two were fixed on its thorax edges and two on the prosternum. On 2 August 2019, a maggot left the bug's body from the abdominal extremity and after about one hour formed its puparium, immediately after the parasitized female died. A male of T. pennipes (Fig. 3) emerged from the puparium 15 days later. On 5 August 2019, and exactly in Petri dish number 4 a second maggot left the male bug's body and it was a really thin maggot, it formed its puparium but it didn't produce any fly. Later on 10

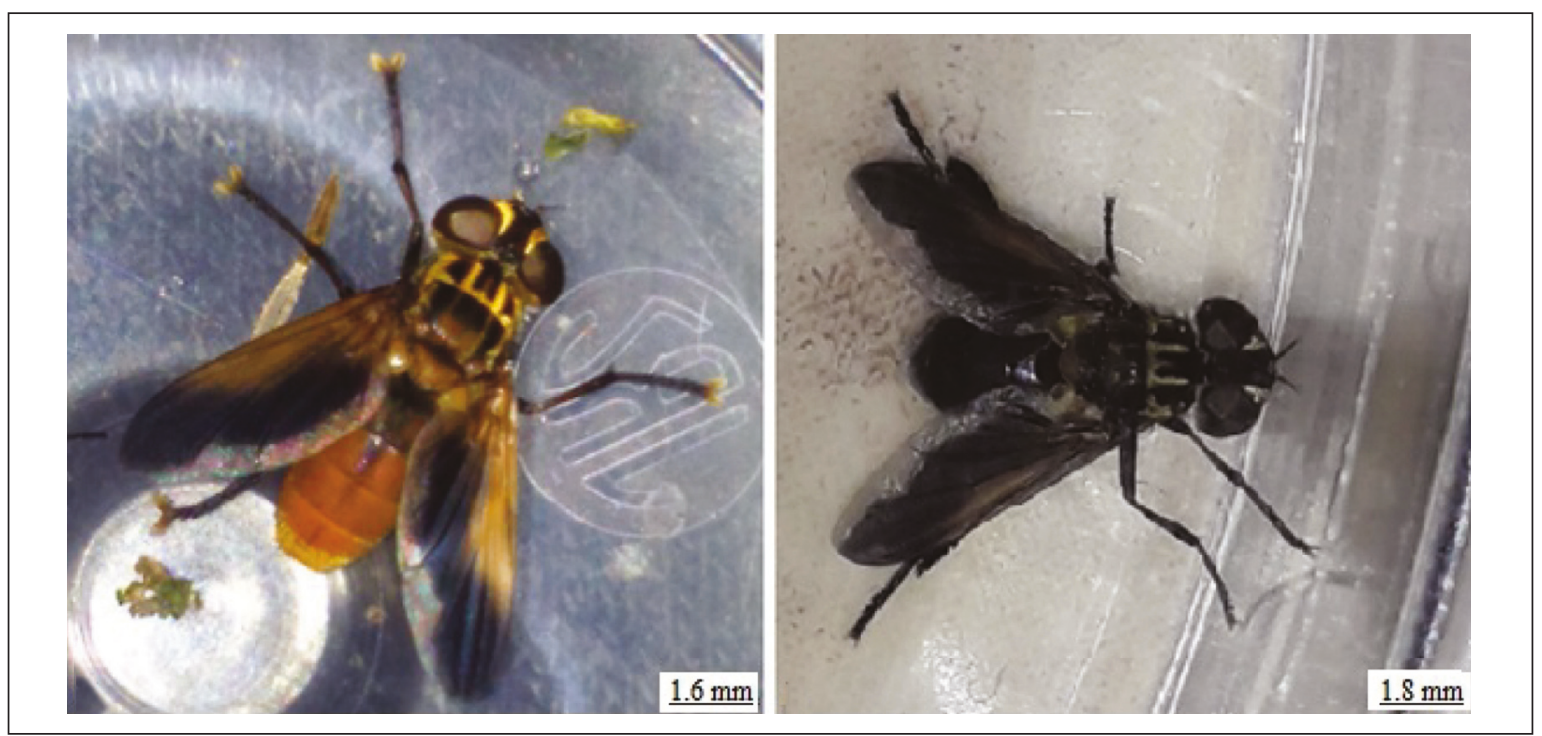

Figure 3. Specimens of Trichopoda pennipes emerged from the parasitized bugs Nezara viridula. Male of Trichopoda pennipes (to the left). Female of Trichopoda pennipes (to the right). 


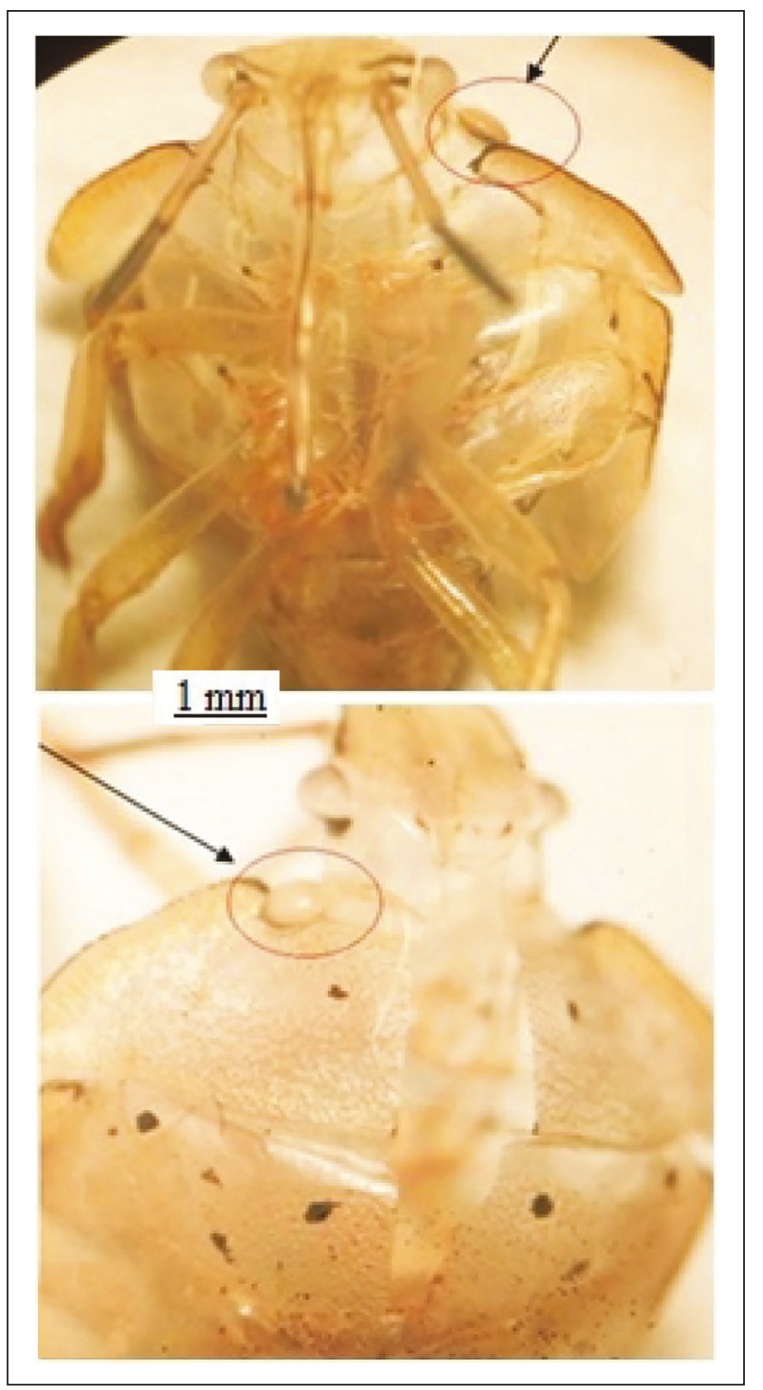

Figure 4. Egg of $T$. pennipes in the exoskeleton of the final nymphal instar of $N$. viridula.

August 2019, other 3 maggots left the bodies of 3 female bugs in Petri dishes number 7, 5 and 2 respectively. Sixteen days later, we found two male of the feather-legged fly emerged in Petri dishes number 7 and 2. One day later a female of T. pennipes emerged from the puparium in Petri dish number 5 and it was the only female (Fig. 3). The last two parasitized bugs in Petri dishes number 3 and 6 died soon after the maggot exit on 17 and 22 August 2019 respectively and didn't produce any fly. About The parasitized final nymphal instar died in Petri dish 8 during the ecdysis before the maggot exit. We observed that its exoskeleton was carrying an egg on the corner between the head and the tho$\operatorname{rax}$ (Fig. 4).

\section{Morphological description of Trichopoda pennipes detected in Algeria}

Four adults of T. pennipes have been emerged from their puparia, 3 males and one female. In general, the males' size is about $7 \mathrm{~mm}$ and for the female is $10 \mathrm{~mm}$; they have a remarkable colored appearance. The color golden-yellow is centered as stripes on the head and the thorax. The abdomen is orange and the wings are brown. They also have a special identification feature which is the feathers on the posterior leg exactly in the tibia which appear obviously (Fig. 5).

The difference between the two sexes is not difficult. We distinguished male and female by their specific coloration. Generally, the three males have a yellowish-orange appearance. Two large shining yellow-golden lines around the eyes in the head, the thorax has three thick vertical black strips surrounded by a bright yellow-golden color in the rest of the thorax surface, the abdomen is dark in the top, and then it goes to orange in the middle. The wing is characterized by a color gradation. At the edge of the wing of the male, there is a light brown large strip, which goes to dark black in the center. The female appearance is darker than the males. It has a black abdomen, a black thorax and black wings with a grey-brown top border.

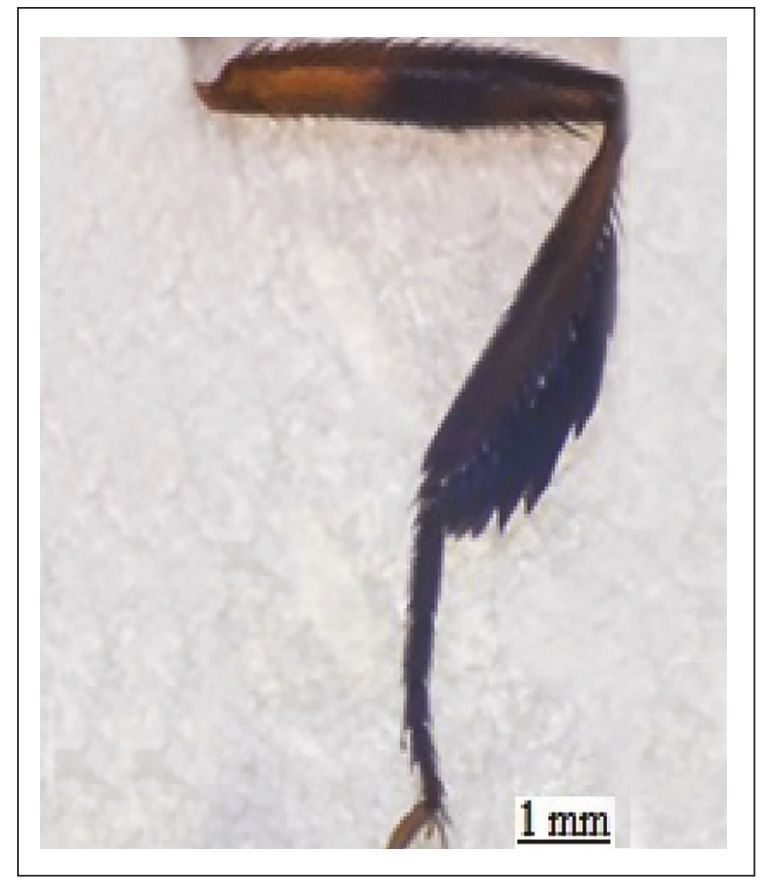

Figure 5. Feathered leg. 


\section{DISCUSSION}

It is difficult to know how and when and from where exactly this parasitoid arrived to Algeria, as this is the first time to study the southern green stink bug $N$. viridula in Algeria. T. pennipes may have reached Algeria from other nearby Mediterranean countries like Spain, Italy and France, where it abundantly exists. The use of the tachinid fly as a biocontrol agent is very important to control $N$. viridula as some attempts of its introduction were successful in Hawaii and California (Davis, 1964; Pickett et al., 1996). Salerno et al. (2002) observed a maximum rate of parasitism of nearly $25 \%$ of $N$. viridula populations by $T$. pennipes in various crops distributed in two areas of central Italy. A $100 \%$ rate of parasitism of $N$. viridula has been reported in Hawaii (Davis, 1964; Michael, 1981). However, some experiments of the $T$. pennipes introduction and establishments have failed in Australia between 1940 and 1950 (Michael, 1981) and recently in 1990 (Waterhouse, 1998). Michael (1981) supposed that the failure of the fly's establishment after its introduction and efforts of rearing back to the insufficient number of this parasitoid.

\section{CONCLUSIONS}

The rearing of the southern green stink bug $N$. viridula from tomato crop in the region of Ouled Hadedj in the eastern part of Mitidja, Algeria which has been done for a comprehensive study of this pest detect the presence of some parasitized individuals. The isolation and the monitoring of these parasitized bugs revealed the first record of the parasitoid T. pennipes which can be a very useful addition for the biodiversity of the country and for the distribution of this tachinid. The parasitoid can be tested as a biological control agent to solve the wide fast reproduction and spread of the southern green stink bug.

\section{ACKNOWLEDGEMENTS}

We are very grateful to Mr. Doumandii Salaheddine, Professor at the department of Zoology in the Higher National Agronomic School (ENSA, El Harrach/Algiers, Algeria) for his help in the identification and the confirmation of the species and also
Professor Tschorsnig Hans-Peter, an entomologist that specializes in caterpillar flies at the Natural History Museum in Stuttgart, Germany for the confirmation of the genus of the species and for giving us the information about the geographic distribution of it. We would also like to extend our special thanks to Mr. Hamitouch Mohamed, agricultural engineer from the department of agricultural hydraulics $/ \mathrm{Ge}-$ nie rural in the Higher National Agronomic School (ENSA, El Harrach/Algiers, Algeria) for his help in achieving the map of the study site.

\section{REFERENCES}

Cargnus E., Buian F.M. \& Zandigiacomo P., 2011. Presenza di Trichopoda pennipes (Diptera, Tachinidae) nell'Italia nord-orientale. Bollettino della Società dei Naturalisti "Silvia Zenari", 35: 123-130.

Colazza S., Giangiuliani G. \& Bin F., 1996. Fortuitous introduction and successful establishment of Trichopoda pennipes: adult parasitoid of Nezara viridula (1.). Biological Control, 6: 409-411. https://doi.org/10.1006/bcon.1996.0053.

Davis C.J., 1964. The introduction, propagation, liberation and establishment of parasites to control Nezara viridula variety smaragdina (Fabricius) in Hawaii (Heteroptera: Pentatomidae). Proceedings of the Hawaiian Entomological Society, 18: 369375.

De Groot M., Virant-Doberlet M. \& Žunič A., 2007. Trichopoda pennipes F. (Diptera, Tachinidae): a new natural enemy of Nezara viridula (L.). Slovenia: short communication. Agricultura, 5: 25-26.

El-Hawagry M.C.A., Ebrahim A.M.E. \& Nada M.S.E., 2020. First detection of the Nearctic parasitoid species Trichopoda pennipes (Fabricius) (Diptera: Tachinidae) in Egypt. Egyptian Journal of Biological Pest Control, (2020) 30: 12. https://org/10.1186/s41938-020-0211-z.

Francati S., Dimattia B.G. \& Martini A., 2019. Acceptance and suitability of Nezara viridula nymphs as hosts for Trichopoda pennipes. Bulletin of Insectology, 72: 55-60.

Jones W.A., 1988. World review of the parasitoids of the southern green stink bug, Nezara viridula (L.) (Heteroptera: Pentatomidae). Annals of the Entomological Society of America, 81: 262-273.

Michael P.J., 1981. Trichopoda: a tricky parasite. The Journal of Agriculture, Western Australia Series 4, 22: $56-57$.

O'Hara J.E., 2013. History of tachinid classification (Diptera, Tachinidae). ZooKeys, 316: 1-34. https://doi.org/10.3897/zookeys.316.5132 
Obrecht E., 2014. Erstfunde von Trichopoda pennipes (Fabricius, 1781) (Diptera, Tachinidae) in der Schweiz, und eine Würdigung einer Amateurentomologin. Contributions to Natural History, 25: 71-79.

Peris S.V., 1998. Un Trichopodini (Diptera, Tachinidae, Phasiinae) en España. Boletín de la Real Sociedad Española de Historia Natural, 94: 163-164.

Pétremand G., Rochefort S., Jaccard G. \& Fischer S., 2015. First detection of the southern green stink bug parasitoid Trichopoda pennipes (Fabr.) (Diptera: Tachinidae) in western Switzerland. Mitteilungen der Schweizerischen Entomologischen Gesellschaft, 88: 403-409.

Pickett C.H., Schoenig S.E. \& Hoffmann M.P., 1996. Establishment of the squash bug parasitoid, Trichopoda pennipes fabr. (Diptera: Tachinidae), in northern California. The Pan-Pacific Entomologist, 72: 220-226.

Ruberson J.R., Olson D.M., Thompson M.D., Ottens R.J., Toews M.D., Jones S. \& Mills W.A., 2010. Importance of natural enemies for stink bug control. In: Ritchie G., Smith A., Collins G. (Eds.), Cotton Research-Extension Report. UGA/CPES Research-Extension Publication.

http://www.ugacotton.com/vault/rer/2009/p126RER2 009.pdf.

Salerno G., Colazza S. \& Bin F., 2002. Nezara viridula parasitism by the Tachinid fly Trichopoda pennipes ten years after its accidental introduction into Italy from the New World. Biocontrol, 47: 617-624.

Sándor N., 2014. A parasitic Trichopoda fly killing southern green stink bugs arrives in Hungary. Available from:

http://nagyelte.blogspot.de/2014/10/trichopoda-pen nipes-fly-parasitizing.html. Accessed 10 Dec 2019.

Todd J.W., 1989. Ecology and behavior of Nezara viridula. Annual Review of Entomology, 34: 273292.

Tschorsnig H-P., Zeegers T. \& Holstein J., 2000. Further records of the introduced parasitoid Trichopoda pennipes (Fabricius, 1781) (Diptera, Tachinidae) from northeastern Spain and southern France. Boletín de la Real Sociedad Española de Historia Natural, 96: 215-216.

Tschorsnig H-P., Cerretti P. \& Zeegers T., 2012. Eight "alien" tachinids in Europe? The Tachinid Times, 25: 11-13.

Waterhouse D.F., 1998. Biological control of insect pests: Southeast Asian prospects. Australian Centre for International Agricultural Research, 51: 1-548.

Worthley H.N., 1924. The biology of Trichopoda pennipes Fab. (Diptera, Tachinidae), a parasite of the common squash bug. Part 1. Psyche, 31: 7-16.

Zeegers T., 2010. Tweede aanvulling op de naamlijst van Nederlandse sluipvliegen (Diptera: Tachinidae). Nederlandse Faunistische Mededelingen, 34: 55-66. 
First record of the feather-legged fly Trichopoda pennipes (Diptera Tachinidae) a parasitoid of the southern green stink bug Nezara viridula (Hemiptera Pentatomidae) in Algeria 